\title{
MECHANICAL AND ELECTRICAL PROPERTIES OF THE Bi-Ge-Sn ALLOYS
}

\author{
Aleksandar Đorđevićl ${ }^{1}$, Milena Premović, ${ }^{1, *}$, Duško Minić ${ }^{1}$, Milica Tomović ${ }^{1}$, \\ Branko Radičević ${ }^{2}$, Nenad Kolarevic ${ }^{3}$ \\ ${ }^{1}$ University of Priština, Faculty of Technical Science, KnezaMiloša 7, \\ 38220 Kos. Mitrovica, Serbia \\ ${ }^{2}$ University of Kragujevac, Faculty of Mechanical and Civil Engineering in Kraljevo, \\ $R S$ \\ ${ }^{3}$ University of Belgrade, Faculty of Mechanical Engineering, Belgrade, RS
}

Received 11.09.2020

Accepted 02.11.2020

\begin{abstract}
Mechanical and electrical properties of the ternary Bi-Ge-Sn alloys were investigated in this study. Calculation of isothermal section at 200,300 , and $25^{\circ} \mathrm{C}$ was carried out by using optimized thermodynamic parameters for the constitutive binary systems. Microstructures of alloys were observed by using optical microscopy and scanning electron microscopy (SEM). Phases in microstructures have been detected by $\mathrm{X}$-ray diffraction (XRD) analysis and compositions of the phase by energy dispersive spectrometry (EDS). EDS results were compared with the predicted isothermal section at 200 and $300{ }^{\circ} \mathrm{C}$, and good agreement has been reached between them. The Brinell hardness and electrical conductivity of selected alloys were measured. Through ANOVA analysis and application of the obtained results, an appropriate mathematical model is proposed for every composition of alloys. By using the appropriated mathematical model for Brinell hardness and electrical conductivity, isolines for those properties were presented.
\end{abstract}

Keywords: ternary Bi-Ge-Sn system; microstructures; hardness properties; electrical properties.

\section{Introduction}

As the properties of the material can be changed with the addition of other elements, the testing of alloys with different compositions is always current, in a way to obtain alloys with new properties. Due to the technical importance of germanium-based 
systems, our group has previously tested germanium-based systems [1-3]. Experimental examination and thermodynamic description of the ternary Bi-Ge-Sn system have been investigated by Đorđevićet al. [4]. The electrical and mechanical properties of the ternary $\mathrm{Bi}-\mathrm{Ge}-\mathrm{Sn}$ system have not been investigated before. Germanium-based alloys are mainly used as memory materials [5-8] and for the production of DVDs, optical, flash andBlueRay disks, etc. On the other hand, those alloys are important semiconductors [9]. By the addition of $\mathrm{Bi}$ to $\mathrm{Ge}$-based materials, their semiconducting properties can be changed considerably, which may be utilized for the development of completely new types of semiconducting materials [10]. Because of all that, experimental investigation of electrical and mechanical properties of the ternary $\mathrm{Bi}-\mathrm{Ge}-\mathrm{Sn}$ alloys at room temperature $\left(\approx 25^{\circ} \mathrm{C}\right)$, as well as isothermal sections on 200 and $300{ }^{\circ} \mathrm{C}$, is shown in this study. Thermodynamic data proposed by Đorđevićet al. [4] havebeen used in our study for the calculation of selected isothermal sections. Alloys of the tested ternary system were exposed to the Brinell hardness test and test for electrical conductivity. Additionally, phase equilibria of the isothermal sections at 200,300 and $25^{\circ} \mathrm{C}$ have been investigated using scanning electron microscopy (SEM) with energy dispersive spectrometry (EDS) and X-ray diffraction (XRD). The results obtained in this paper were intended to provide a better insight into the properties of the test alloys.

\section{Materials and Methods}

All tested samples (ternary and binary) with total masses of about $5 \mathrm{~g}$ were prepared from high purity elements (99.999 at. \%) Bi, Ge, and Sn. Samples were melted in an induction furnace under a high purity argon atmosphere and slowly cooled. The average weight loss of the samples during the induction melting was about 1 mass $\%$. Samples for investigation of isothermal sections at $200{ }^{\circ} \mathrm{C}$ and $300{ }^{\circ} \mathrm{C}$, were sealed in evacuated quartz tubes and then heated to the appropriate temperatures. Then they were extinguished in the water and ice mixture to preserve the desired equilibrium at appropriate temperatures $\left(200\right.$ and $\left.300{ }^{\circ} \mathrm{C}\right)$. The samples prepared in this way were examined by SEM-EDS and XRD analysis. Brinell hardness and electrical conductivity tests were performed on the samples cooled to room temperature.

The compositions of samples and coexisting phases were determined by using JEOL JSM-6460 scanning electron microscope with energy dispersive spectroscopy (EDS) (Oxford Instruments X-act). Powder XRD data for phase identification of samples were recorded on a D2 PHASER (Bruker, Karlsruhe, Germany) powder diffractometer equipped with a dynamic scintillation detector and ceramic X-ray $\mathrm{Cu}$ tube (KFL-Cu-2K) in a $2 \theta$ range from $10^{\circ}$ to $75^{\circ}$ with a step size of $0.02^{\circ}$. The patterns were analyzed using the Topas 4.2 software, ICDD databases PDF2. Microstructures of the samples were recorded on light microscopy using (LOM) OLYMPUS GX41 inverted metallographic microscope. Hardnesses of the samples were measured using Brinell hardness tester INNOVATEST, model NEXUS 3001. Electrical conductivity measurements were carried out using Foerster SIGMATEST 2.069 eddy current instrument.

\section{Results and discussion}

Constitutive binary systems of the ternary Bi-Ge-Sn system were extensively studied in the past. Reliable thermodynamic datasets for these binary systems are available in the literature [11-13]. Based on the literature information for binary sub- 
systems considered phase, their crystallographic data and database names for the solid phases are summarized in Table 1.

Table 1. Considered phase, their crystallographic data and database names for the solid phases of the ternary Bi-Ge-Sn system.

\begin{tabular}{lllll}
\hline $\begin{array}{l}\text { Thermodynamic } \\
\text { database name }\end{array}$ & $\begin{array}{l}\text { Common } \\
\text { name }\end{array}$ & $\begin{array}{l}\text { Space group } \\
\text { symbol }\end{array}$ & $\begin{array}{l}\text { Structural } \\
\text { designation }\end{array}$ & $\begin{array}{l}\text { Pearson's } \\
\text { symbol }\end{array}$ \\
\hline LIQUID & Liquid & - & - & - \\
RHOMBO_A7 & $(\mathrm{Bi})$ & $R^{3} m H$ & $A 7$ & $h R 2$ \\
DIAMOND_A4 & $(\mathrm{Ge})$ & $F m^{3} m$ & $A 4$ & $c F 8$ \\
DIAMOND_A4 & $(\alpha \mathrm{Sn})$ & $F d^{3} m$ & $A 4$ & $c F 8$ \\
BCT_A5 & $(\beta \mathrm{Sn})$ & $I 4_{1} /$ amd & $A 5$ & $t I 4$ \\
\hline
\end{tabular}

In the ternary Bi-Ge-Sn system, the liquid phase and four solid solution phases should appear: $(\mathrm{Bi}),(\mathrm{Ge}),(\alpha \mathrm{Sn})$, and $(\beta \mathrm{Sn})$.

Ternary Bi-Ge-Sn system

Isothermal section at $200^{\circ} \mathrm{C}$

For the investigation of the phase equilibria at $200{ }^{\circ} \mathrm{C}$, five samples were analyzed by SEM-EDS and XRD methods. Experimental results are summarized in Table 2.

As can be seen from the presented EDS and XRD results, all studied alloy samples have the same $\mathrm{L}$ and $(\mathrm{Ge})$ solid solution phase in the microstructure. In addition to the liquid phase and (Ge) solid solution phase, in the samples, 4 and 5 (Bi) solid solution phase occurs. The EDS results show that $(\mathrm{Ge})$ solid solution phase is rich with germanium with neglected solubility of the other two elements. (Bi) solid solution phase is rich with bismuth and with neglected solubility of germanium and tin. The liquid phase is rich with $\mathrm{Bi}$ and Sn.

SEM micrograph of one sample annealed at $200{ }^{\circ} \mathrm{C}$ is presented in Figure 1 as an illustration.

On the given micrograph, $(\mathrm{Ge})$ solid solution phase appears as a dark phase and $\mathrm{L}$ phase as a light phase.

Since the samples were annealed at $200^{\circ} \mathrm{C}$, compositions of the phases determined by EDS analysis were compared with the calculated isothermal section at $200{ }^{\circ} \mathrm{C}$. Figure 2 shows a comparison of the EDS results (Table 2) and the calculated isothermal section at $200{ }^{\circ} \mathrm{C}$. 
Table 2. Combined results of SEM-EDS and XRD analyzes of the selected Bi-Ge-Sn alloys annealed at $T=200^{\circ} \mathrm{C}$.

\begin{tabular}{|c|c|c|c|c|c|c|c|c|}
\hline \multirow{2}{*}{$\mathrm{N}$. } & \multirow{2}{*}{$\begin{array}{l}\text { Composition } \\
\text { of samples } \\
(\text { at. } \%)\end{array}$} & \multicolumn{2}{|c|}{$\begin{array}{l}\text { Determined } \\
\text { phases }\end{array}$} & \multicolumn{3}{|c|}{ Compositions of phases (at. \%) } & \multicolumn{2}{|c|}{ Lattice parameters $(\AA)$} \\
\hline & & EDS & $\begin{array}{l}\mathrm{XR} \\
\mathrm{D} \\
\end{array}$ & $\mathrm{Bi}$ & $\mathrm{Ge}$ & Sn & $a=b$ & $c$ \\
\hline 1. & $\begin{array}{l}10.90 \mathrm{Bi} \\
55.27 \mathrm{Ge} \\
33.83 \mathrm{Sn}\end{array}$ & $\begin{array}{l}\mathrm{L} \\
(\mathrm{Ge})\end{array}$ & $(\mathrm{Ge})$ & $\begin{array}{l}27.01 \pm 0.7 \\
0.33 \pm 0.4\end{array}$ & $\begin{array}{l}1.82 \pm 0.2 \\
98.87 \pm 0.1\end{array}$ & $\begin{array}{l}71.17 \pm 0.4 \\
0.80 \pm 0.7\end{array}$ & $\begin{array}{l}5.6545 \pm \\
0.0002\end{array}$ & \\
\hline 2. & $\begin{array}{l}22.28 \mathrm{Bi} \\
19.14 \mathrm{Ge} \\
58.58 \mathrm{Sn}\end{array}$ & $\begin{array}{l}\mathrm{L} \\
(\mathrm{Ge})\end{array}$ & $(\mathrm{Ge})$ & $\begin{array}{l}30.21 \pm 0.6 \\
0.65 \pm 0.7\end{array}$ & $\begin{array}{l}2.63 \pm 0.5 \\
99.12 \pm 0.4\end{array}$ & $\begin{array}{l}67.16 \pm 0.1 \\
0.23 \pm 0.2\end{array}$ & $\begin{array}{l}5.6589 \pm \\
0.0007\end{array}$ & \\
\hline 3. & $\begin{array}{l}\text { 33.97 } \mathrm{Bi} \\
33.67 \mathrm{Ge} \\
32.36 \mathrm{Sn}\end{array}$ & $\begin{array}{l}\mathrm{L} \\
(\mathrm{Ge})\end{array}$ & $(\mathrm{Ge})$ & $\begin{array}{l}27.02 \pm 0.3 \\
0.82 \pm 0.7\end{array}$ & $\begin{array}{l}3.03 \pm 0.6 \\
98.99 \pm 0.1\end{array}$ & $\begin{array}{l}69.95 \pm 0.7 \\
0.19 \pm 0.9\end{array}$ & $\begin{array}{l}5.6536 \pm \\
0.0004\end{array}$ & \\
\hline 4. & $\begin{array}{l}45.96 \mathrm{Bi} \\
44.53 \mathrm{Ge} \\
9.51 \mathrm{Sn}\end{array}$ & $\begin{array}{l}\mathrm{L} \\
(\mathrm{Ge}) \\
(\mathrm{Bi})\end{array}$ & $\begin{array}{l}(\mathrm{Ge}) \\
(\mathrm{Bi})\end{array}$ & $\begin{array}{l}10.87 \pm 0.7 \\
0.57 \pm 0.7 \\
99.12 \pm 0.7\end{array}$ & $\begin{array}{l}5.01 \pm 0.4 \\
98.25 \pm 0.8 \\
0.18 \pm 0.9\end{array}$ & $\begin{array}{l}84.12 \pm 0.8 \\
1.18 \pm 0.7 \\
0.70 \pm 0.2\end{array}$ & $\begin{array}{l}5.6512 \pm \\
0.0006 \\
4.5367 \pm \\
0.0004 \\
\end{array}$ & $\begin{array}{l}11.8124 \pm \\
0.0006\end{array}$ \\
\hline 5. & $\begin{array}{l}63.79 \mathrm{Bi} \\
13.61 \mathrm{Ge} \\
22.60 \mathrm{Sn}\end{array}$ & $\begin{array}{l}\mathrm{L} \\
(\mathrm{Ge}) \\
(\mathrm{Bi})\end{array}$ & $\begin{array}{l}(\mathrm{Ge}) \\
(\mathrm{Bi})\end{array}$ & $\begin{array}{l}7.53 \pm 0.9 \\
1.07 \pm 0.2 \\
98.76 \pm 0.1\end{array}$ & $\begin{array}{l}5.27 \pm 0.7 \\
98.12 \pm 0.7 \\
0.62 \pm 0.8\end{array}$ & $\begin{array}{l}87.20 \pm 0.8 \\
0.81 \pm 0.1 \\
0.62 \pm 0.9\end{array}$ & $\begin{array}{l}5.6578 \pm \\
0.0005 \\
4.5398 \pm \\
0.0006\end{array}$ & $\begin{array}{l}11.8179 \pm \\
0.0003\end{array}$ \\
\hline
\end{tabular}

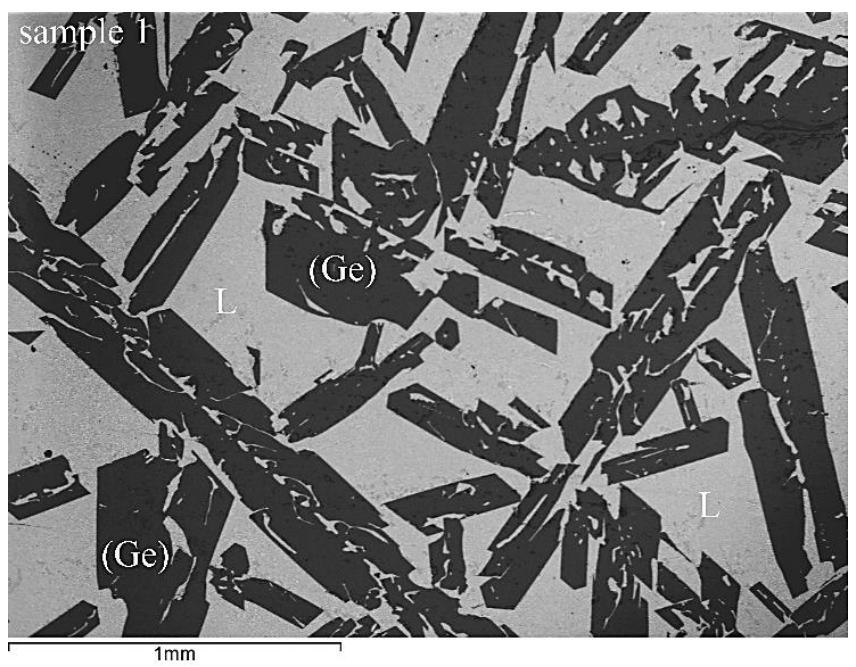

Fig. 1. SEM micrographs of sample 1 annealed at $200{ }^{\circ} \mathrm{C}$. 


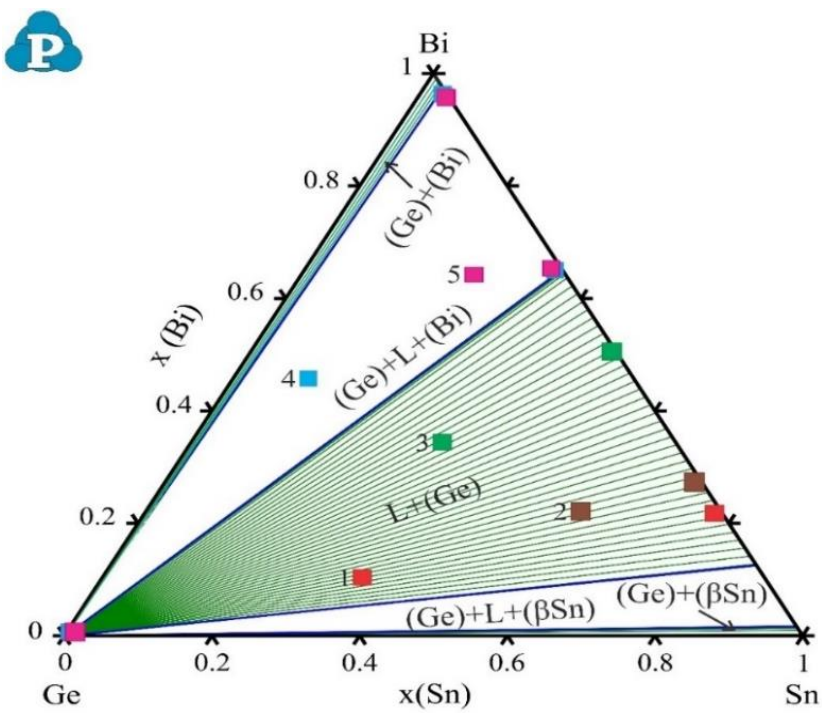

Fig. 2. The calculated isothermal section at $200^{\circ} \mathrm{C}$ compared with EDS results given in Table 2.

From Figure 2 it can be seen that the calculated isothermal section has five phase regions. Three of them are $\mathrm{L}+(\mathrm{Ge}),(\mathrm{Ge})+(\beta \mathrm{Sn})$ and $(\mathrm{Ge})+(\mathrm{Bi})$ two-phase regions, two are $(\mathrm{Ge})+\mathrm{L}+(\mathrm{Bi})$ and $(\mathrm{Ge})+\mathrm{L}+(\beta \mathrm{Sn})$ three-phase regions. Two of the three-phase regions have been experimentally proven. Tested alloy samples 1,2 , and 3 belong to $\mathrm{L}+(\mathrm{Ge})$ two-phase region. Samples 4 and 5 belong $(\mathrm{Ge})+\mathrm{L}+(\mathrm{Bi})$ three-phase region.

\section{Isothermal section at $300^{\circ} \mathrm{C}$}

As a next step, five alloys annealed at $300{ }^{\circ} \mathrm{C}$ were used for checking phase equilibria at $300{ }^{\circ} \mathrm{C}$. Results of SEM-EDS and XRD analysis for the alloys annealed at $300{ }^{\circ} \mathrm{C}$ are summarized in Table 3 .

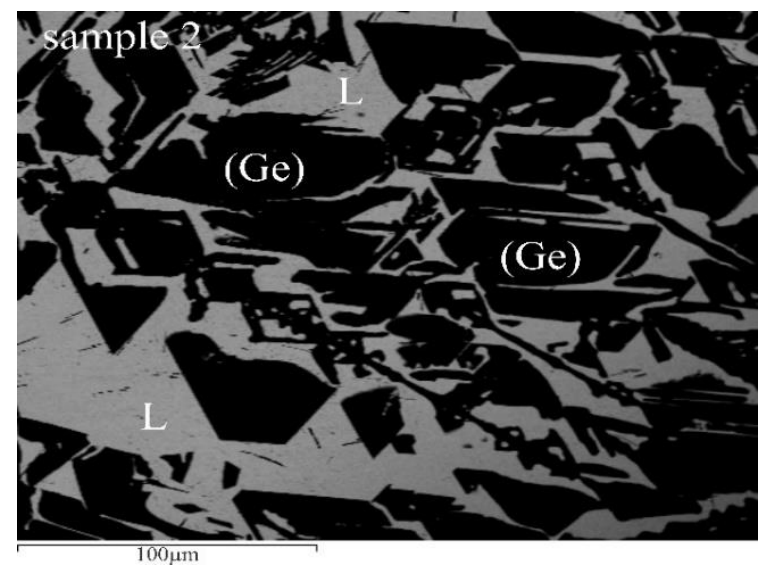

Fig. 3. SEM micrographs of the sample2 annealed at $300^{\circ} \mathrm{C}$. 
Table 3. Combined results of SEM-EDS and XRD analyzes of the selected Bi-Ge-Sn alloys annealed at $T=300^{\circ} \mathrm{C}$.

\begin{tabular}{|c|c|c|c|c|c|c|c|}
\hline \multirow{2}{*}{ N. } & \multirow{2}{*}{$\begin{array}{l}\text { Composition } \\
\text { of samples } \\
\text { (at. \%) }\end{array}$} & \multicolumn{2}{|c|}{$\begin{array}{l}\text { Determined } \\
\text { phases }\end{array}$} & \multicolumn{3}{|c|}{ Compositions of phases (at. \%) } & \multirow{2}{*}{$\begin{array}{l}\text { Lattice parameters }(\AA) \\
a=b=c\end{array}$} \\
\hline & & EDS & XRD & $\mathrm{Bi}$ & $\mathrm{Ge}$ & Sn & \\
\hline 1. & $\begin{array}{l}13.03 \mathrm{Bi} \\
22.91 \mathrm{Ge} \\
64.06 \mathrm{Sn} \\
\end{array}$ & $\begin{array}{l}\mathrm{L} \\
(\mathrm{Ge})\end{array}$ & (Ge) & $\begin{array}{l}23.98 \pm 0.7 \\
0.78 \pm 0.7\end{array}$ & $\begin{array}{l}0.24 \pm 0.4 \\
98.78 \pm 0.2\end{array}$ & $\begin{array}{l}75.78 \pm 0.2 \\
0.44 \pm 0.4\end{array}$ & $5.6523 \pm 0.0006$ \\
\hline 2. & $\begin{array}{l}36.75 \mathrm{Bi} \\
16.77 \mathrm{Ge} \\
46.48 \mathrm{Sn} \\
\end{array}$ & $\begin{array}{l}\mathrm{L} \\
(\mathrm{Ge})\end{array}$ & $(\mathrm{Ge})$ & $\begin{array}{l}24.91 \pm 0.6 \\
0.42 \pm 0.8\end{array}$ & $\begin{array}{l}1.92 \pm 0.3 \\
98.21 \pm 0.1\end{array}$ & $\begin{array}{l}73.17 \pm 0.8 \\
1.37 \pm 0.5\end{array}$ & $5.6568 \pm 0.0001$ \\
\hline 3. & $\begin{array}{l}16.29 \mathrm{Bi} \\
60.83 \mathrm{Ge} \\
22.88 \mathrm{Sn} \\
\end{array}$ & $\begin{array}{l}\mathrm{L} \\
(\mathrm{Ge})\end{array}$ & (Ge) & $\begin{array}{l}38.63 \pm 0.2 \\
0.28 \pm 0.4\end{array}$ & $\begin{array}{l}1.52 \pm 0.3 \\
99.07 \pm 0.7\end{array}$ & $\begin{array}{l}59.85 \pm 0.1 \\
0.65 \pm 0.9\end{array}$ & $5.6561 \pm 0.0007$ \\
\hline 4. & $\begin{array}{l}60.18 \mathrm{Bi} \\
23.01 \mathrm{Ge} \\
16.81 \mathrm{Sn} \\
\end{array}$ & $\begin{array}{l}\mathrm{L} \\
(\mathrm{Ge})\end{array}$ & $(\mathrm{Ge})$ & $\begin{array}{l}41.87 \pm 0.3 \\
0.82 \pm 0.1\end{array}$ & $\begin{array}{l}0.24 \pm 0.6 \\
98.91 \pm 0.7\end{array}$ & $\begin{array}{l}57.89 \pm 0.3 \\
0.27 \pm 0.2\end{array}$ & $5.6569 \pm 0.0002$ \\
\hline 5. & $\begin{array}{l}53.36 \mathrm{Bi} \\
23.30 \mathrm{Ge} \\
23.34 \mathrm{Sn} \\
\end{array}$ & $\begin{array}{l}\mathrm{L} \\
(\mathrm{Ge})\end{array}$ & $(\mathrm{Ge})$ & $\begin{array}{l}21.13 \pm 0.3 \\
0.47 \pm 0.8\end{array}$ & $\begin{array}{l}0.62 \pm 0.2 \\
99.11 \pm 0.4\end{array}$ & $\begin{array}{l}78.25 \pm 0.9 \\
0.42 \pm 0.5\end{array}$ & $5.6530 \pm 0.0006$ \\
\hline
\end{tabular}

Detected phases are $\mathrm{L}$ and (Ge) solid solution. (Ge) a solid solution is rich with germanium and can dissolve a neglected amount of tin and bismuth. EDS result shows that $\mathrm{L}$ phase has different composition depending on the composition of the samples. In general $\mathrm{L}$ phase is rich in tin and bismuth and dissolves a negligible amount of germanium.

SEM micrographs of sample 2 annealed at $300{ }^{\circ} \mathrm{C}$ present in Figure 3.

From the microstructure, it is visible that $(\mathrm{Ge})$ solid solution appears as a dark phase and L phase a gray phase.

The EDS results obtained for the samples annealed at $300{ }^{\circ} \mathrm{C}$ are given in Table 3 and compared with the calculated isothermal section at $300{ }^{\circ} \mathrm{C}$. Figure 4 presents a comparison of the calculated phase diagram and the EDS results. 


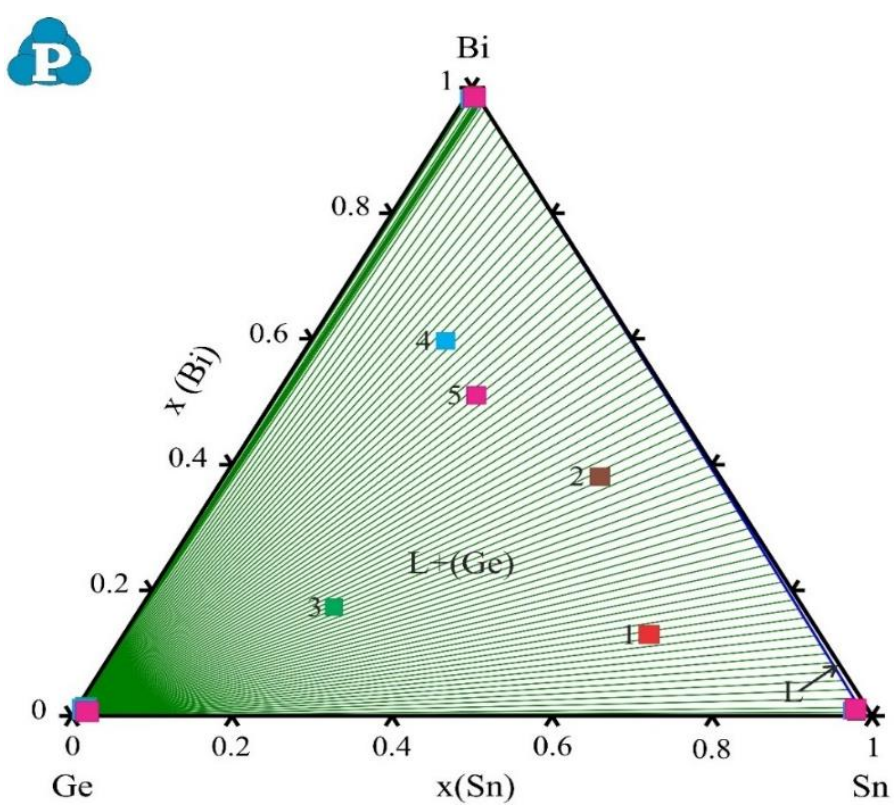

Fig. 4. The calculated isothermal section at $300^{\circ} \mathrm{C}$ compared with EDS results given in Table 3.

The calculated isothermal cross-section at $300^{\circ} \mathrm{C}$ consists of two-phase regions. One is a single-phase region $\mathrm{L}$, and the other is a two-phase region $\mathrm{L}+(\mathrm{Ge})$. By comparing the EDS composition of the tested samples, it is determined that all samples are from the two-phase $\mathrm{L}+(\mathrm{Ge})$ region, the same region as the experimentally detected samples. The EDS phase compositions agree well with the calculated phase compositions.

\section{Microstructural analysis of slowly-cooled samples}

Twelve slowly cooled ternary samples, marked with numbers from 1 to 12 , were subjected to the tests of mechanical and electrical properties. Overall compositions of samples were situated along three vertical sections (samples 1 to 4 , along Bi-GeSn vertical section, samples 5 to 8 along Ge-BiSn vertical section, and samples from 9 to 12 along $\mathrm{Sn}-\mathrm{BiGe}$ vertical section). Figure 5 presents the calculated isothermal section at $25^{\circ} \mathrm{C}$ with a marked nominal composition of tested ternary alloys. 


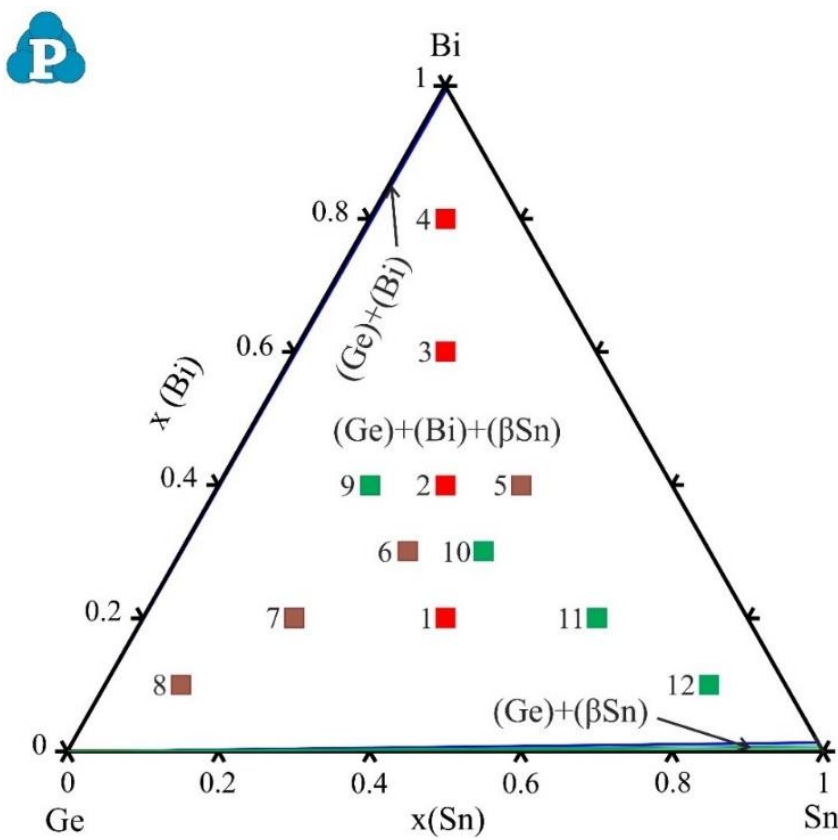

Fig. 5. The predicted isothermal section at $25{ }^{\circ} \mathrm{C}$ with marked compositions

$$
\text { of tested alloys. }
$$

Before determining hardness and electrical conductivity, samples were analyzed using XRD, and their microstructure was observed with light optical microscopy. Results of XRD analysis of all samples revealed that all samples have $(\mathrm{Ge}),(\mathrm{Bi})$, and $(\beta \mathrm{Sn})$ phases in microstructure. Three microstructures of samples 1,4 , and 7 are given in Figure 6. Phases that appear in microstructures are marked at presented micrographs.

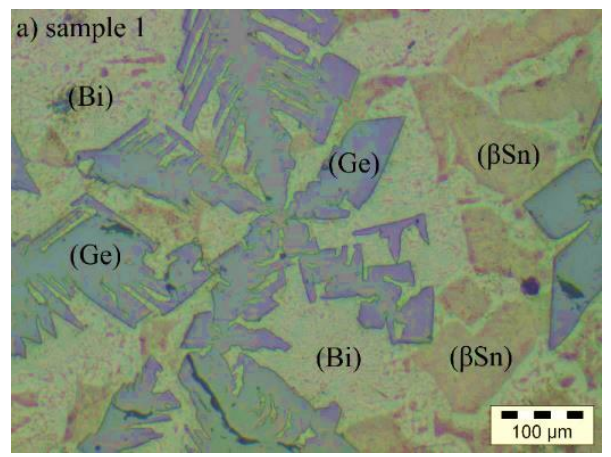

a)

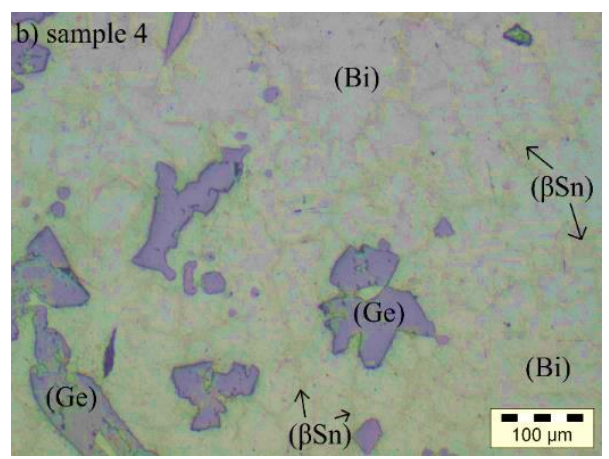

b) 


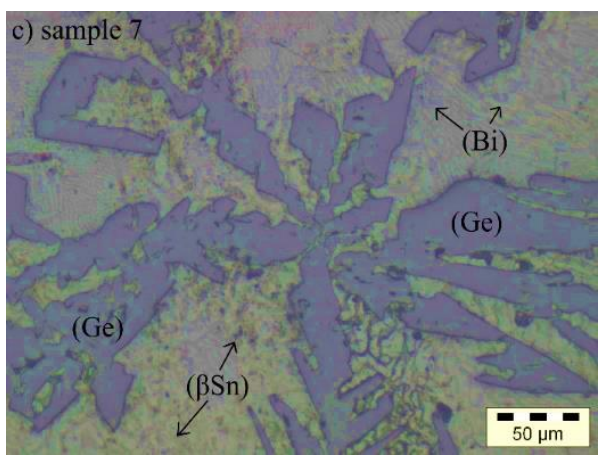

c)

Fig. 6. LOM micrographs of a) sample 1, b) sample 4, and c) sample 7.

\section{Brinell hardness measurements}

Twelve ternary samples and three binary samples were subjected to the Brinell hardness measurements. Based on repeated measurements, the mean values of Brinell hardness were calculated and presented in Table 4. Literature values of hardness for pure elements [14] are also shown in Table 4 for comparison.

Table 4. Compositions of the investigated samples at room temperature and related Brinell hardness values.

\begin{tabular}{llllllll}
\hline \multirow{2}{*}{ N. } & \multicolumn{2}{l}{ Alloy nominal composition (at.\%) } & \multicolumn{3}{l}{ Measured value $\left(\mathrm{MN} / \mathrm{m}^{2}\right)$} & \multicolumn{2}{l}{ Mean value } \\
& $\mathrm{x}(\mathrm{Bi})$ & $\mathrm{x}(\mathrm{Ge})$ & $\mathrm{x}(\mathrm{Sn})$ & 1 & 2 & 3 & $\left(\mathrm{MN} / \mathrm{m}^{2}\right)$ \\
\hline $\mathrm{B} 1$ & $\mathbf{0}$ & 0.5 & 0.5 & 19.40 & 24.20 & 18.60 & 20.73 \\
1 & $\mathbf{0 . 2}$ & 0.4 & 0.4 & 27.80 & 28.00 & 28.30 & 28.03 \\
2 & $\mathbf{0 . 4}$ & 0.3 & 0.3 & 23.90 & 26.20 & 24.80 & 24.96 \\
3 & $\mathbf{0 . 6}$ & 0.2 & 0.2 & 22.60 & 22.00 & 24.40 & 23.00 \\
4 & $\mathbf{0 . 8}$ & 0.1 & 0.1 & 23.60 & 19.10 & 20.20 & 20.96 \\
$\mathrm{Bi}$ & $\mathbf{1}$ & 0 & 0 & & & & $94.20[14]$ \\
$\mathrm{B} 2$ & 0.5 & $\mathbf{0}$ & 0.5 & 15.40 & 12.30 & 16.20 & 14.63 \\
5 & 0.4 & $\mathbf{0 . 2}$ & 0.4 & 31.90 & 32.70 & 32.30 & 32.30 \\
6 & 0.3 & $\mathbf{0 . 4}$ & 0.3 & 38.80 & 43.10 & 42.80 & 41.56 \\
7 & 0.2 & $\mathbf{0 . 6}$ & 0.2 & 41.60 & 46.20 & 44.80 & 44.20 \\
8 & 0.1 & $\mathbf{0 . 8}$ & 0.1 & 63.30 & 58.50 & 56.20 & 59.33 \\
$\mathrm{Ge}$ & 0 & $\mathbf{1}$ & 0 & & & & $973.40[14]$ \\
$\mathrm{B} 3$ & 0.5 & 0.5 & $\mathbf{0}$ & 213.20 & 215.60 & 217.40 & 215.40 \\
9 & 0.4 & 0.4 & $\mathbf{0 . 2}$ & 37.30 & 38.00 & 39.00 & 38.10 \\
10 & 0.3 & 0.3 & $\mathbf{0 . 4}$ & 35.50 & 36.80 & 34.90 & 35.73 \\
11 & 0.2 & 0.2 & $\mathbf{0 . 6}$ & 43.40 & 42.10 & 42.80 & 42.76 \\
12 & 0.1 & 0.1 & $\mathbf{0 . 8}$ & 39.90 & 42.30 & 41.20 & 41.13 \\
$\mathrm{Sn}$ & 0 & 0 & $\mathbf{1}$ & & & & $51.00[14]$ \\
\hline
\end{tabular}


In addition to the tabular presentation, the obtained values for hardness are also presented graphically. Figure 7 shows a graphical representation of the relationship between the hardness of the tested alloys and the composition of the alloys.

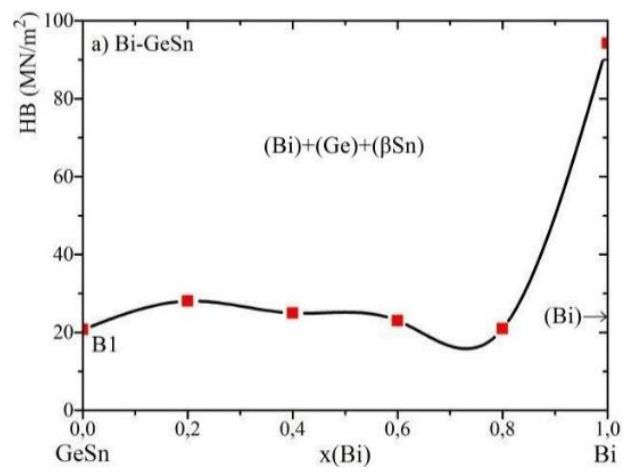

a)

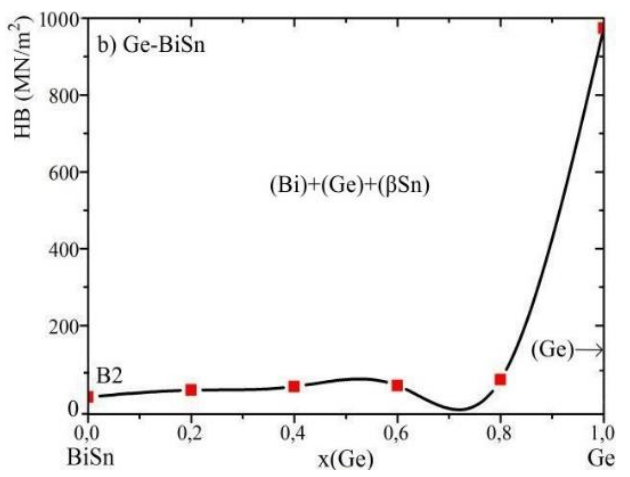

b)

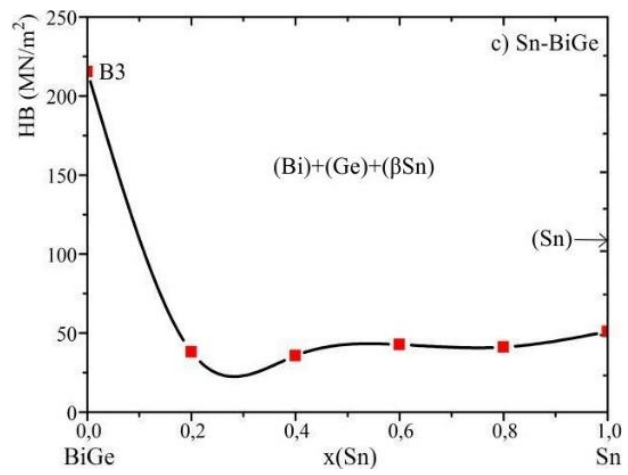

c)

Fig. 7. Graphical presentation of Brinell hardness dependence of composition and phase fraction: a) vertical section Bi-GeSn, b) vertical section Ge-BiSn and c) vertical section

\section{Sn-BiGe.}

The highest value of hardness for ternary alloys was measured on the sample $\mathrm{Bi}_{10} \mathrm{Ge}_{80} \mathrm{Sn}_{10}$ of $59.33 \mathrm{MN} / \mathrm{m}^{2}$, which is understandable due to the high amount of germanium. Since all tested alloys have the same three phases in microstructure $(\mathrm{Bi})+(\mathrm{Ge})+(\beta \mathrm{Sn})$ experimental results did not detect a big jump in experimentally determined values. The big difference between alloy 4 and pure $\mathrm{Bi}$ is due to the difference in microstructure so pure $\mathrm{Bi}$ has much higher hardness compared to ternary alloys rich with $\mathrm{Bi}$, since in the microstructure of alloys 4 three phases are in equilibrium $(\mathrm{Bi})+(\mathrm{Ge})+(\beta \mathrm{Sn})$.

As none of the S-models (Scheffe-model) met the adequacy requirements, the socalled SV-models (Slack-Variable mixture models) were used [15,16]. The Quartic Slack 
Mixture model was selected. By utilizing experimentally determined values of hardness given in Table 5 mathematical model of the dependence of the Brinell hardness on composition for the Bi-Ge-Sn alloys was developed. The diagnosis of the statistical properties of the assumed model found that the distribution of residuals is not normal and that it is necessary to transform the mathematical model in order to meet the conditions of normality. The Box-Cox diagnostics recommends the "Inverse Square Root" transformation for the variance stabilization.

The final equation of the predictive model in terms of Real components is:

$$
1 / \operatorname{Sqrt}(\mathrm{HB})=0.0317625+0.07459893 \cdot(\mathrm{Bi})+1.39074537 \cdot(\mathrm{Sn})-3.14882 \cdot(\mathrm{Bi}) \cdot(\mathrm{Sn})
$$

$-0.0033572 \cdot\left(B i^{2}\right)-2.7651581 \cdot\left(S^{2}\right)+4.02037782 \cdot\left(B i^{2}\right) \cdot(S n)+3.92451675 \cdot(B i) \cdot\left(S^{2}\right)$

$+1.48355978 \cdot\left(\mathrm{Sn}^{3}\right)-3.2914706 \cdot\left(B i^{2}\right) \cdot\left(\mathrm{Sn}^{2}\right)$

The repeated analysis for Inverse Square Root model transformation confirms the significance of the Transformed Quartic Slack Mixture model. In this case, ANOVA confirms the adequacy of the Reduced Quartic Slack Mixture model (Table 5).

Table 5. ANOVA for Reduced Quartic Slack Mixture model.

\begin{tabular}{|c|c|c|c|c|c|c|}
\hline Source & $\begin{array}{l}\text { Sum } \\
\text { Squares }\end{array}$ & of & df & $\begin{array}{l}\text { Mean } \\
\text { Square } \\
\end{array}$ & $\begin{array}{l}\mathrm{F} \\
\text { Value }\end{array}$ & $\begin{array}{l}\text { p-value } \\
\text { Prob }>F\end{array}$ \\
\hline Model & 0.05065 & & 9 & 0.00563 & 35.49194 & 0.00002 \\
\hline $\mathrm{A}-\mathrm{Bi}$ & 0.00022 & & 1 & 0.00022 & 1.40959 & 0.26918 \\
\hline C-Sn & 0.00593 & & 1 & 0.00593 & 37.37938 & 0.00029 \\
\hline $\mathrm{AC}$ & 0.00362 & & 1 & 0.00362 & 22.82148 & 0.00140 \\
\hline$A^{2}$ & 0.00000 & & 1 & 0.00000 & 0.00310 & 0.95699 \\
\hline$C^{2}$ & 0.00286 & & 1 & 0.00286 & 18.04155 & 0.00281 \\
\hline $\mathrm{A}^{2} \mathrm{C}$ & 0.00597 & & 1 & 0.00597 & 37.62949 & 0.00028 \\
\hline $\mathrm{AC}^{2}$ & 0.00175 & & 1 & 0.00175 & 11.06407 & 0.01044 \\
\hline $\mathrm{C}^{3}$ & 0.00185 & & 1 & 0.00185 & 11.65229 & 0.00917 \\
\hline $\mathrm{A}^{2} \mathrm{C}^{2}$ & 0.00118 & & 1 & 0.00118 & 7.44329 & 0.02592 \\
\hline Residual & 0.00127 & & 8 & 0.00016 & & \\
\hline Cor Total & 0.05191 & & 17 & & & \\
\hline
\end{tabular}

The F-value of the Model is 35,49and it implies that the model is significant. In this case, all model terms are significant. R-squared and other statistics after the ANOVA have appropriate values which confirm the justification of the choice of the adopted mathematical model (Table 6). 
Table6. $R$-squared and other statistics after the ANOVA.

\begin{tabular}{llll}
\hline Std. Dev. & 0.01259 & R-Squared & 0.97557 \\
Mean & 0.16054 & Adj R-Squared & 0.94808 \\
C.V. \% & 7.84322 & Pred R-Squared & 0.78256 \\
PRESS & 0.01129 & Adeq Precision & 24.09909 \\
\hline
\end{tabular}

The diagnosis of the statistical properties of the assumed model found that the distribution of residuals is normal. After the applied Box-Cox procedure, the value of $\lambda$ is -0.5 , the optimum value of $\lambda$ is -0.26 , and the $95 \%$ confidence interval for $\lambda$ (Low C.I. $=$ 0.79 , High C.I. $=0.11$ ) contains the value -0.5 , thus proving the justification of the model transformation (Figure 8).

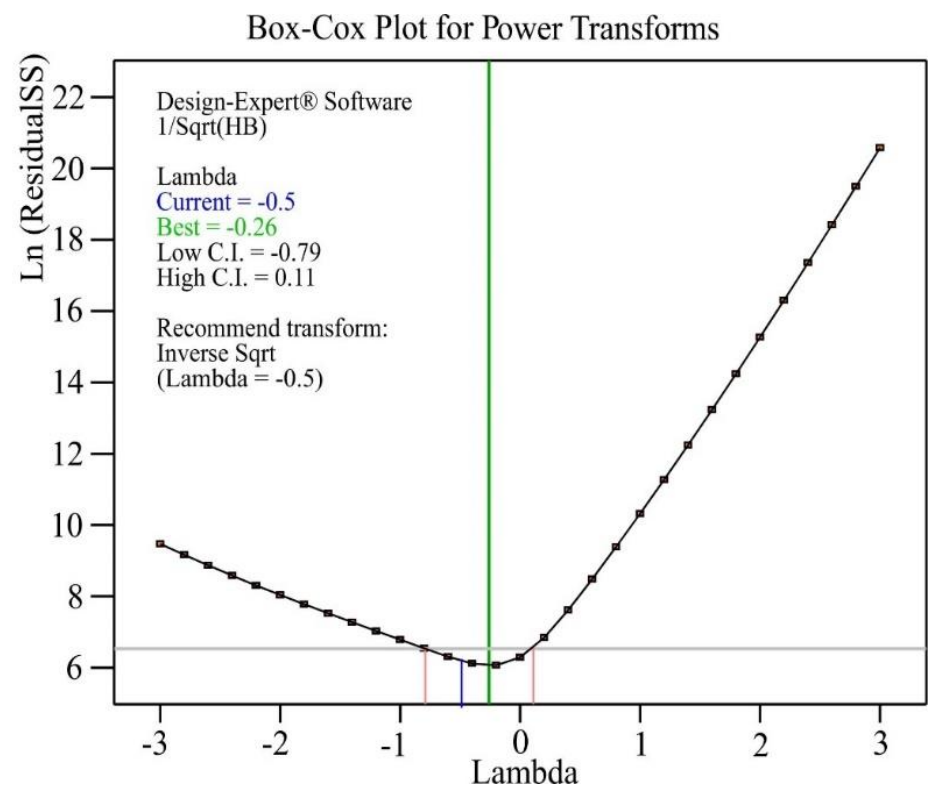

Fig. 8. The Box-Cox plot for power transforms.

Iso-lines contour plot for Brinell hardness of alloys defined by equation 1 is shown in Figure 9. 


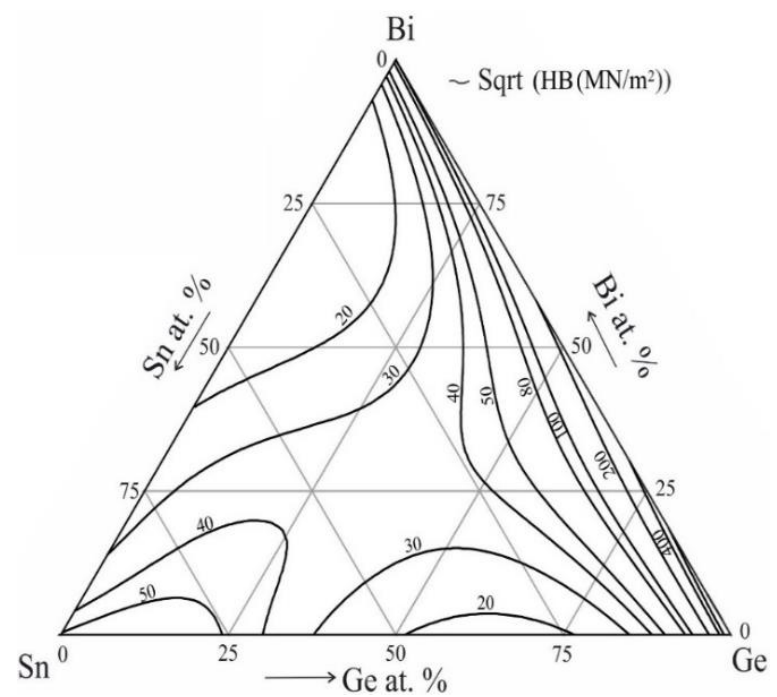

Fig. 9. Calculated iso-lines of Brinell hardness in the ternary Bi-Ge-Sn system with $R^{2}=0.976$.

\section{Electrical conductivity measurements}

Measurements of electrical conductivity were performed on the same group of samples used for the hardness test. For all investigated samples, electrical conductivity measurements were repeated four times at different positions, and obtained values for each measured point are given in Table 7. Besides measured values, Table 7 also includes calculated mean values and literature values of electrical conductivity for pure elements [17].

Figure 10 presents a graphical presentation of results (mean value) given in Table 7 for an easier overview of the results.

\section{Sn-BiGe.}

According to the obtained results, the triple alloy $\mathrm{Bi}_{10} \mathrm{Ge}_{10} \mathrm{Sn}_{80}$ has the highest value of electrical conductivity, $3.0290 \mathrm{MS} / \mathrm{m}$, which is expected because, in this combination of bismuth, germanium, and tin, tin has the highest electrical conductivity compared to the other two components.

The Special Quartic Mixture model was suggested as a final equation for the prediction of electrical conductivity. The diagnosis of the statistical properties of the assumed model found that the distribution of residuals is not normal and that it is necessary to transform the mathematical model in order to meet the conditions of normality. The Box-Cox diagnostics recommend the "Square Root" transformation for the variance stabilization. 
Table 7. Compositions of the investigated samples at room temperature and related electrical conductivity values.

\begin{tabular}{|c|c|c|c|c|c|c|c|c|}
\hline \multirow[t]{2}{*}{ N. } & \multicolumn{3}{|c|}{$\begin{array}{l}\text { Alloy nominal } \\
\text { composition (at.\%) }\end{array}$} & \multicolumn{4}{|c|}{ Value (MS /m) } & \multirow{2}{*}{$\begin{array}{l}\text { Mean } \\
\text { value } \\
(\mathrm{MS} / \mathrm{m})\end{array}$} \\
\hline & $\mathrm{x}(\mathrm{Bi})$ & $\mathrm{x}(\mathrm{Ge})$ & $\mathrm{x}(\mathrm{Sn})$ & 1 & 2 & 3 & 4 & \\
\hline B1 & 0 & 0.5 & 0.5 & 2.8010 & 2.7370 & 2.7800 & 2.7680 & 2.7710 \\
\hline 1 & 0.2 & 0.4 & 0.4 & 0.5323 & 0.7698 & 0.6397 & 0.7885 & 0.6825 \\
\hline 2 & 0.4 & 0.3 & 0.3 & 0.4978 & 0.4757 & 0.5042 & 0.4989 & 0.4941 \\
\hline 3 & 0.6 & 0.2 & 0.2 & 0.8899 & 0.6365 & 0.7895 & 0.6325 & 0.7371 \\
\hline 4 & 0.8 & 0.1 & 0.1 & 0.9636 & 0.9800 & 0.9993 & 0.8998 & 0.9606 \\
\hline $\mathrm{Bi}$ & 1 & 0 & 0 & & & & & $0.77[17]$ \\
\hline B2 & 0.5 & $\mathbf{0}$ & 0.5 & 1.3699 & 1.0236 & 1.3698 & 1.0233 & 1.1966 \\
\hline 5 & 0.4 & 0.2 & 0.4 & 0.8161 & 0.8317 & 0.8561 & 0.8383 & 0.8355 \\
\hline 6 & 0.3 & 0.4 & 0.3 & 0.7896 & 0.6356 & 0.7853 & 0.6669 & 0.7193 \\
\hline 7 & 0.2 & 0.6 & 0.2 & 0.3168 & 0.3156 & 0.3147 & 0.3158 & 0.3157 \\
\hline 8 & 0.1 & 0.8 & 0.1 & 0.3695 & 0.2225 & 0.2314 & 0.2323 & 0.2639 \\
\hline $\mathrm{Ge}$ & 0 & 1 & 0 & & & & & $0.002[17]$ \\
\hline B3 & 0.5 & 0.5 & $\mathbf{0}$ & 0.3430 & 0.3410 & 0.3530 & 0.3440 & 0.3452 \\
\hline 8 & 0.4 & 0.4 & 0.2 & 0.3080 & 0.3068 & 0.3091 & 0.3087 & 0.3081 \\
\hline 10 & 0.3 & 0.3 & 0.4 & 0.3889 & 0.4545 & 0.5232 & 0.4999 & 0.4666 \\
\hline 11 & 0.2 & 0.2 & 0.6 & 2.0450 & 1.9999 & 2.0050 & 2.0254 & 2.0188 \\
\hline 12 & 0.1 & 0.1 & 0.8 & 3.1232 & 3.1252 & 2.9362 & 2.9316 & 3.0290 \\
\hline Sn & 0 & 0 & 1 & & & & & $9.1[17]$ \\
\hline
\end{tabular}

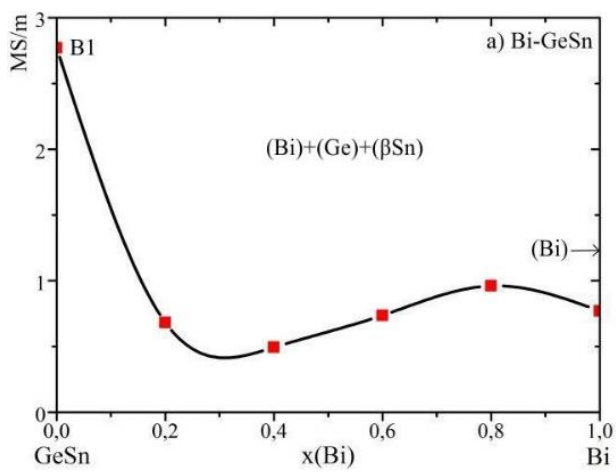

a)

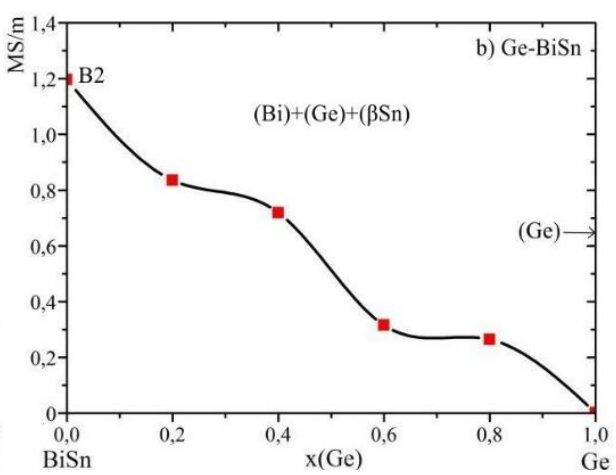

b) 


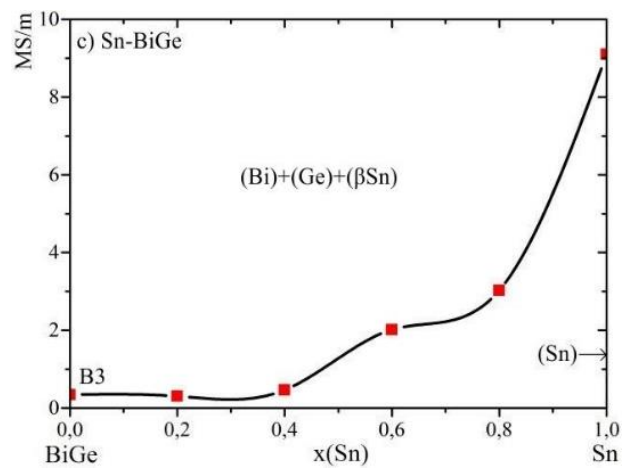

c)

Fig. 10. Graphical presentation of electrical conductivity dependence of composition and phase fraction a) vertical section Bi-GeSn, b) vertical section Ge-BiSn and c) vertical section.

The final equation of the predictive model in terms of actual components is:

$\operatorname{Sqrt}(\sigma)=0.976127 \cdot(\mathrm{Bi})+0.0501598 \cdot(\mathrm{Ge})+2.8830787 \cdot(\mathrm{Sn})+0.4271847 \cdot(\mathrm{Bi}) \cdot(\mathrm{Ge})-$ $3.0859792 \cdot(\mathrm{Bi}) \cdot(\mathrm{Sn})+0.514126 \cdot(\mathrm{Ge}) \cdot(\mathrm{Sn})-26.711332 \cdot(\mathrm{Bi}) \cdot(\mathrm{Ge}) \cdot\left(\mathrm{Sn}^{2}\right)$

The repeated analysis for the Square Root model transformation confirms the significance of the Transformed Special Quartic Mixture model. In this case, ANOVA confirms the adequacy of the Special Quartic Mixture model (Table 8).

The F-value of the Model is 48.76, and it implies that the model is significant. Rsquared and other statistics after the ANOVA have good values that confirm the justification of the choice of the adopted mathematical model (Table 9).

The diagnosis of the statistical properties of the assumed model found that the distribution of residuals is normal. After the applied Box-Cox procedure, the value of $\lambda$ is 0.5 , the optimum value of $\lambda$ is 0.32 , and the $95 \%$ confidence interval for $\lambda$ (Low C.I. $=0.10$, High C.I. $=0.55$ ) contains the value 0.5 , thus proving the justification of the model transformation (Figure 11).

Table 8.ANOVA for Special Quartic Mixture model.

\begin{tabular}{llllll}
\hline Source & Sum of Squares & df & Mean Square & $\begin{array}{l}\text { F } \\
\text { Value }\end{array}$ & $\begin{array}{l}\text { p-value } \\
\text { Prob > F }\end{array}$ \\
\hline Model & 6.97359 & 6 & 1.16227 & 48.75690 & 0.00000027 \\
Linear Mixture & 5.68286 & 2 & 2.84143 & 119.19764 & 0.00000004 \\
AB & 0.00972 & 1 & 0.00972 & 0.40762 & 0.53624788 \\
AC & 0.43643 & 1 & 0.43643 & 18.30800 & 0.00130137 \\
BC & 0.01211 & 1 & 0.01211 & 0.50815 & 0.49078544 \\
ABC $^{\wedge}$ & 0.18397 & 1 & 0.18397 & 7.71754 & 0.01796658 \\
Residual & 0.26222 & 11 & 0.02384 & &
\end{tabular}




Cor Total $\quad 7.23581 \quad 17$

Table 9. R-squared and other statistics after the ANOVA.

\begin{tabular}{llll}
\hline Std. Dev. & 0.15440 & R-Squared & 0.96376 \\
Mean & 0.99388 & Adj R-Squared & 0.94399 \\
C.V. \% & 15.53469 & Pred R-Squared & 0.81299 \\
PRESS & 1.35317 & Adeq Precision & 29.42299 \\
\hline
\end{tabular}

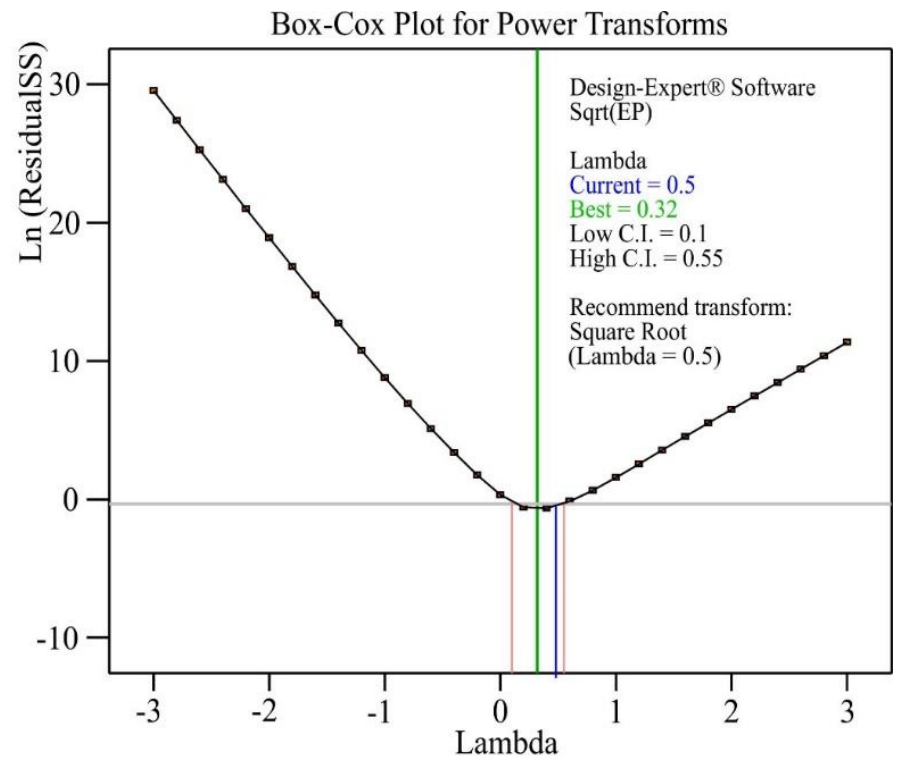

Fig. 11. The Box-Cox plot for power transforms.

Iso-lines contour plot for Electrical conductivity of Bi-Ge-Sn alloys defined by equation 2 is shown in Figure 12. 


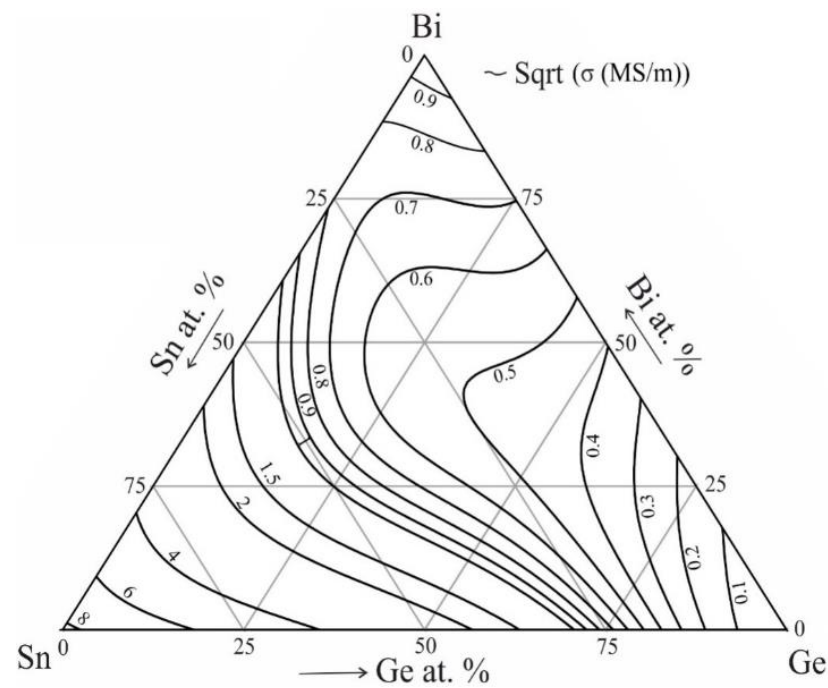

Fig. 12. Calculated iso-lines of Electrical conductivity in the ternary Bi-Ge-Sn system with $R^{2}=0.964$.

\section{Conclusion}

In this study, three isothermal sections at 200,300 , and $25^{\circ} \mathrm{C}$ are experimentally investigated for the ternary Bi-Ge-Sn system. SEM-EDS and XRD analysis were applied for the analysis of the chosen ternary samples after long-term annealing. Experimental results obtained by SEM-EDS and XRD techniques were compared with calculated phase diagrams at 200 and $300{ }^{\circ} \mathrm{C}$, and good agreement between data is reached. By using the thermodynamic data set, the isothermal section at $25{ }^{\circ} \mathrm{C}$ was calculated, and three different phase fields were predicted. One of the three-phase regions was confirmed with EDS and XRD results. On twelve ternary alloys and three binary alloys, microstructural, hardness, and electrical conductivity tests were performed. With SEM and LOM, microstructures of tested alloys were observed. On $25{ }^{\circ} \mathrm{C}$ detected phases with XRD method are $(\mathrm{Ge}),(\mathrm{Bi})$, and $(\beta \mathrm{Sn})$ solid solutions. All results from the Brinell hardness test and electrical conductivity were used for predicting a mathematical model for calculation of properties along with all composition range.

\section{Acknowledgements}

This work has been supported by the National Nature Science Foundation of China (project No.51950410600) and the Ministry of Education, Science and Technological Development of the Republic of Serbia (Grant No. OI172037). 


\section{References}

[1] M.Premovic, D.Minić, M.Kolarevic, D.Manasijevic, D.Živković, A. Djordjevic, D.Milisavljevic:Rev Metal., 53(3) (2017) e098.

[2] M. Premović, D.Manasijević, D.Minić, D.Živković: Kovové Mater., 54(1) (2016) 45-53.

[3] M. Premovic, Y. Du, D. Minic, C. Zhang, D.Manasijevic, Lj.Balanovic, I. Markovic:J. Alloy Compd., 726 (2017) 820.

[4] A. Djordjević,D. Minić,M. Premović,D. Manasijević,V.Ćosović:JPED, 40(4) (2019) 623-637.

[5] A. L. Lacaita, D.J.Wouters:Phys. Status Solidi A Appl. Mater., 205 (2008) 2281.

[6] S. L. Ou, C. P. Cheng, C. Y. Yeh, C.J. Chung, K. S. Kao, R. C. Lin:Adv. Mater. Res., 189 (2011) 4430.

[7] D. Ielmini, A. L.Lacaita:Mater. Today, 14(12) (2011) 600

[8] P. Nemec, V.Nazabal, A.Moreac, J.Gutwirth, L. Benes, M.Frumar,Mater. Chem. Phys., 136 (2012) 935.

[9] V. Tomashyk, Ternary Alloys Based on III-V Semiconductors, CRC Press, 2017.

[10] L. Tichy, H. Tichá, A. Pacesová, J. Petzlt,J. Non-Cryst. Solids., 128(2) (1991) 191-196.

[11] P. Y. Chevalier: Thermochim. Acta, 132 (1988) 111-116.

[12] J. Vizdal, M. H.Braga, A.Kroupa, K. W. Richter, D. Soares,L. F. Malheiros, J. Ferreira: Calphad, 31 (2007) 438-448.

[13] Y. Feutelais, B. Legendre, S. G. Fries:Calphad, 20(1) (1996) 109-123.

[14] http://periodictable.com/Properties/A/BrinellHardness.al.html, access 29.11.2018

[15] C. S. Javier: Ingeniería Investigación y Tecnología,14(4) (2015) 613-623.

[16] G. F. Piepel, D. C. Hoffmann, S. K. Cooley, Slack-Variable versus Mixture Modeling for Mixture Experiments: A Definitive Comparison, 2018.

[17] http://periodictable.com/Properties/A/ElectricalConductivity.an.html, access 25.12.2018

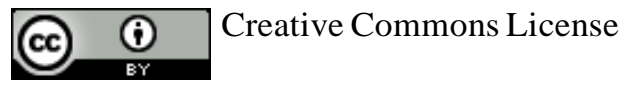

This work is licensed under a Creative Commons Attribution 4.0 International License. 